\title{
Pengaruh Dakwah Jamaah Tabligh Terhadap Pembangunan Masyarakat Muslim di Lombok Sejak Tahun 2011-2016
}

\author{
M. Zaki Abdillah \\ Program Studi Komunikasi Penyiaran Islam, Fakultas Agama Islam \\ Universitas Muhammadiyah Mataram,83115, Indonesia \\ ibanee@gmail.com
}

INFO ARTIKEL

Riwayat Artikel:

Diterima Desember 2017

Direvisi Januari 2018

Disetujui Februari 2018
AB STR A KS I

Abstrak: Jamaah Tabligh merupakan salah satu gerakan dakwah dalam Islam yang berasal dari India. Gerakan ini masuk ke pulau Lombok sekitar awal tahun 1990-an. Kehadiran gerakan ini melahirkan fenomena baru dalam kehidupan sebagian masyarakat Islam di Lombok. Gerakan ini telah berhasil menanamkan pengaruhnya tidak hanya kepada golongan kelas bawah, tapi juga golongan elit dari kalangan pejabat dan pengusaha. Kajian ini bertujuan menganalisa kelompok ini dari aspek pengaruhnya terhadap pembangunan masyarakat Muslim secara lebih luas seperti politik, ekonomi dan sosial. Bentuk kajian ini adalah deskriptifkualitatif. Teknik yang digunakan untuk memperoleh data adalah dokumentasi, observasi dan wawancara yang melibatkan 21 responden. Hasil kajian ini menunjukkan bahwa gerakan Jamaah Tabligh memberi pengaruh yang cukup besar terhadap pembangunan masyarakat Muslim di Pulau Lombok. Dari segi politik, gerakan ini telah berhasil menanamkan pengaruhnya terhadap para pejabat sehingga ada beberapa kebijakan yang dilakukan oleh para pejabat bersumber dari doktrin gerakan Jamaah Tabligh. Dari segi ekonomi pula, gerakan ini telah berhasil mengurangkan gaya hidup hedonisme di kalangan pengikutnya. Sedangkan dari segi sosial, gerakan ini memainkan peranan penting terhadap hidupnya suasana ibadah di masjid-masjid. Selain ini gerakan ini juga telah mampu mengurangi perilaku buruk di kalangan masyarakat. Namun demikian terdapat juga beberapa hal yang menjadi perhatian khusus gerakan ini terutama dalam menggunakan hadis-hadis yang banyak berstatus lemah (dha'if). Selain itu pengabdian terhadap anggota keluarga akibat doktrin khuruj juga yang terdapat dalam gerakan Jamaah Tabligh perlu diperhatikan. Namun secara umum gerakan Jamaah Tabligh memberikan pengaruh yang sangat positif terhadap pembangunan moral-spiritual masyarakat di pulau Lombok. Oleh karena itu gerakan dakwah ini perlu didukung bagi memberikan pengaruh yang lebih luas terhadap pembangunan masyarakat selain itu gerakan ini juga perlu menjalin kerjasama dengan organisasiorganisasi dakwah supaya gerakan ini tidak terkesan eksklusif.

Abstract : Jamaah Tabligh is one of the da'wah movements in Islam that originally comes from India. This movement was introduced to Lombok Island in the early 1990s. The presence of this movement gave birth to a new phenomenon in the life of some Islamic societies in Lombok. This movement has succeeded in instilling its influence not only to the lower classes, but also the elite from officials and businessmen. This study aims to analyze this group from influence aspects on the development of a Muslim society wider such as politics, economics and society. The form of this study is descriptive-qualitative. The techniques used to obtain data are documentation, observation and interviews involving 21 respondents. The results of this study proved that the Jamaah Tabligh 
Kata Kunci:

Dakwah Islam ,

Jamaah Tabligh

Metode Deskriptif-Kualitatif

Keywords:

Islamic Da'wah,

Jamaah Tabligh ,

Descriptive-qualitative method movement has a significant influence on the development of Muslim communities on the Lombok island. From a political point of view, this movement has succeeded in instilling its influence on the officials so that there are some policies made by officials sourced from the doctrine of Jamaah Tabligh movement. From an economic point of view, the movement has succeeded in reducing the hedonism lifestyle among its followers. While in terms of social, this movement plays an important role on the life of the atmosphere of worship in the mosques. Besides this movement has also been able to reduce bad behavior among the community. Nevertheless there are also some things of particular concern to this movement, especially in the use of hadiths that are weak (dha'if). In addition, neglect of family members due to doctrine "khuruj" also contained in the Jamaah Tabligh movement needs to be paid attention to. In general, however, the Jamaah Tabligh movement has had a very positive influence on the moral-spiritual development of the people on Lombok island. Therefore, this da'wah movement needs to be supported to give wider influence to community development besides that this movement also need to establish cooperation with da'wah organizations so that this movement does not seem exclusive.

\section{Pendahuluan}

Islam tradisional merupakan salah satu istilah yang dilabelkan kepada kelompok Muslim yang mengedepankan amalan ritual dan penyucian jiwa. Salah satu kelompok yang sangat identik dengan istilah ini adalah gerakan Jamaah Tabligh (JT). Fenomena tradisionalisme Islam yang diusung oleh JT ini mendapat respon yang beragam di kalangan masyarakat Islam di Indonesia khususnya di Pulau Lombok. Doktrin menghidupkan sunah Nabi melalui pendekatan dakwah secara personal ke rumah-rumah, menghindari polemik fikih dan politik serta memakai pakaian khas dan sorban merupakan ciri-ciri paling menonjol yang ada pada kelompok ini.

Walaupun tanggapan masyarakat amat beragam, gerakan JT justeru telah berhasil mengembangkan dakwah mereka hampir ke setiap pelosok wilayah di Pulau Lombok. Hal ini dapat dilihat berdasarkan keikutsertaan masyarakat ke dalam kelompok ini serta kehadiran mereka di masjid-masjid. Tidak susah mengidentifikasi anggota kelompok ini karena mereka memiliki ciri khusus yang hampir dikenal oleh seluruh masyarakat Pulau Lombok. Pun demikian, tidak ada data secara kuantitatif mengenai jumlah anggota gerakan ini karena keanggotaan mereka bersifat lepas dan tidak terdata serta bertebaran di berbagai penjuru.

Keberadaan JT di Pulau Lombok sejak awal tahun 1990-an telah melahirkan fenomena baru dalam kehidupan sebagian masyarakat Islam di Lombok. Gerakan ini telah berhasil menanamkan pengaruhnya tidak hanya kepada golongan kelas bawah, tapi juga golongan elit dari kalangan pejabat dan pengusaha. Keberhasilan merangkul seluruh elemen masyarakat menjadikan gerakan ini menarik untuk dianalisa baik dari segi metodologi dakwah mahupun dari segi dampaknya terhadap pembangunan masyarakat Muslim di Lombok.

Seperti yang telah dinyatakan sebelumnya, terdapat tiga hal fundamental yang menjadi ciri khas gerakan JT yaitu pendekatan dakwah secara personal ke rumah-rumah melalui program khuruj, menghindari polemik fikih dan politik serta memakai pakaian khas ala India. Ketiga ciri ini tentu memiliki dampak terhadap respon dan juga pembangunan masyarakat khususnya jika dilihat dari aspek sosial politik dan budaya. Oleh karenanya persoalan utama yang akan diangkat dalam penelitian ini adalah sejauh mana kehadiran JT ini memberi dampak terhadap pembangunan sosial, politik dan budaya terhadap masyarakat Islam di Lombok.

Masyarakat Lombok, oleh sebagian peneliti dianggap sebagai masyarakat yang taat beragama sekaligus taat berbudaya. Jargon "Lombok Pulau Seribu Masjid" adalah cerminan yang amat jelas 
untuk menunjukkan bahwa masyarakat Lombok adalah masyarakat yang religius. ${ }^{1}$ Selain Jargon "Pulau Seribu Masjid" masyarakat Pulau Lombok juga bisa dilabelkan dengan "Pulau Seribu Tuan Guru" ini karena fungsi, status dan pengaruh Tuan Guru di tengah-tengah masyarakat amat dirasakan. Sesuai dengan gelar yang disematkan oleh masyarakat, Tuan Guru memainkan peranan yang sangat penting dalam menyampaikan ilmu-ilmu agama kepada masyarakat. Dalam menyampaikan ilmu agama, Tuan Guru lazimnya mempunyai lembaga pendidikan berupa pondok pesantren dan biasanya "dihadirkan" oleh masyarakat dalam majelis-majelis keilmuan (pengajian) baik bersifat rutin mahupun pada momentum tertentu. Dari aspek budaya pula, ritual-ritual budaya yang ditampakkan baik melalui amalan mahupun pakaian memberikan gambaran bahwa masyarakat Lombok di samping religius juga sangat taat dalam beradat dan berbudaya. ketaatan masyarakat Lombok dalam beradatbudaya ini bisa dilihat dari berbagai aspek termasuk dalam hal keagamaan.

Adapun dalam bidang politik, terutama setelah penerapan autonomi daerah masyarakat Lombok telah mengalami keterbukaan. Jabatan-jabatan politis yang pada awalnya didominasi oleh kelas perwangsa kini bisa diduduki oleh siapa saja termasuk oleh kalangan Tuan Guru. Bahkan autonomi daerah telah menjadi panggung bagi kalangan Tuan Guru memainkan politik secara praktis. Sehingga hampir di setiap lini demokrasi kalangan Tuan Guru selalu ada untuk mengambil bagian secara aktif.

Kehadiran serta perkembangan gerakan JT yang mengusung tiga prinsip fundamental yang nampaknya bertentangan dengan dinamika sosial, politik dan budaya masyarakat Lombok seakanakan melahirkan kompetisi baru dalam kehidupan masyarakat di Pulau ini. Di satu sisi, masyarakat Lombok sedang mengalami kenyamanan dalam menjalani kehidupan beragama, berbudaya dan berdemokrasi, manakala di sisi lain gerakan JT sedang berusaha melalui dakwahnya untuk menebar prinsip-prinsip agama, politik dan budaya yang berbeda dengan apa yang sedang dijalani oleh masyarakat Lombok.

Oleh itu, penelitian ini mencoba untuk menganalisa satu persoalan yang menarik bagi mengetahui sejauh mana gerakan JT mampu mempengaruhi proses pembangunan masyarakat Lombok melalui tiga dimensi utama iaitu sosial, politik dan budaya yang terangkum dalam sebuah judul : Pengaruh Dakwah Jamaah Tabligh Terhadap Pembangunan Masyarakat Muslim Di Lombok.

Fokus Penelitian ini adalah untuk memudahkan analisis hasil penelitian, maka penelitian ini difokuskan pada kelompok gerakan JT di Pulau Lombok dengan menumpukan JT yang berada di wilayah Mataram.

Rumusan Masalah dalam penelitian ini terdapat beberapa masalah yang telah dirumuskan yaitu : (1) Apa saja pengaruh gerakan JT terhadap masyarakat Muslim di Pulau Lombok? (2) Apa perbedaan metode dakwah gerakan JT dengan gerakan-gerakan lain? (3) Sejauh mana metode dakwah yang diterapkan oleh gerakan ini sejalan dengan sunah Rasul?

Adapun Tujuan Penelitia, berdasarkan latar belakang dan fokus penelitian, terdapat beberapa tujuan yang hendak dicapai dalam penelitian ini (1) Mendeskripsikan pengaruh gerakan JT terhadap pembangunan masyarakat Islam di Lombok. (2) Menjelaskan perbedaan metode dakwah JT dengan gerakan Islam yang lain. (3) Menguraikan sejauh mana metode dakwah JT sejalan dengan sunah Rasul.'

Dalam pelaksanaan Penelitian ini diharapkan dapat menerangkan secara jelas mengenai pengaruh gerakan JT dalam pembangunan masyarakat Islam di Pulau Lombok. Penelitian ini juga diharapkan dapat dijadikan sebagai masukan bagi pemerintah dan pihak-pihak terkait dalam menentukan kebijakan dan pandangan mengenai gerakan dakwah JT. 


\section{Kajian Pustaka}

Penulisan tentang Jamaah Tabligh telah banyak dilakukan, antara lain Amir (1998) meneliti Jamaah Tabligh suatu tinjauan sejarah, Syahruddin (1995) meneliti peranan Jamaah Tabligh dalam pembinaan ummat, Jurjis (2001) tentang perilaku Jamaah Tabligh. Di Lombok kajian mengenai Jamaah Tabligh telah dilakukan antaranya oleh Ihsan \& Hafizi (2015) yang meneliti tentang strategi dakwah Jamaah Tabligh dan perubahan sosial masyarakat dusun Gelogor desa Lendang Nangka, Lombok Timur. Adapun kajian mengenai pengaruh Jamaah Tabligh secara lebih luas di Lombok sejauh ini masih belum ditemukan. Padahal sejauh ini Jamaah Tabligh tidak hanya menancapkan pengaruhnya di tingkat komunitas yang lebih kecil melainkan telah menjadi sebuah gerakan yang mempengaruhi berbagai aspek dalam kehidupan masyarakat. Untuk literatur primer mengenai konsep Jamaah Tabligh itu sendiri penulis menyusun berdasarkan beberapa karya di antaranya karya Mualana Muhammad Zakariya al-Kandahlawi, Himpuna Fadhailul A $^{\prime}$ amal. ${ }^{2}$ Kemudian karya Syeikh Maulana Muhammad Yusuf al-Kandahlawi dan Syeikh Maulana Muhammad Saad al-Kandaklawi dalam kitab Muntakhab al-Ahadits : Dalil-dalil pilihan enam sifat utama. ${ }^{3}$ Kemudian karya Maulana Sayid Muhammad Syahid, Menjawab kritikan atas kitab Fadhailul A'mal. ${ }^{4}$ Dan karya Mulana Wahiduddin Khan, Gerakan Tabligh. ${ }^{5}$

\section{A. Tinjauan Pustaka Tentang Dakwah}

Kata dakwah berasal dari bahasa Arab dari kata dasar da'ā yang berarti menyeru, dan mashdarnya da'wah yang berarti seruan, mengajak, atau panggilan. Jadi dakwah secara bahasa adalah seruan atau ajakan yang dilakukan oleh da'i kepada manusia untuk menjalani hidup di jalan Allah SWT.

Selain makna dakwah, mengajak kejalan Allah atau mengajak kedalam agama Allah dalam Al-Qura'an juga ada ayat dengan makna do'a, (Al-Imran,3:38), makna mendakwa, Maryam: 91, makna mengadu, Al-Qamar: 10 dan banyak lagi yang dipakaikan dalam makna yang berbeda. ${ }^{6}$

Ta'rif tentang dakwah mengalami perkembangan sejalan dengan perkembangan permasalahan dan tantangan dakwah. Muhammad Ali Aziz dalam bukunya "Ilmu Dakwah" telah menghimpun ta'rif dakwah yang diberikan oleh parta ahli sebanyak 39 ta'rif, di antaranya adalah: Menurut Abu Bakar Zakaria dakwah adalah: "Usaha para ulama dan orang-orang yang memiliki pengetahuan agama Islam untuk memberikan pengajaran kepada khalayak umum sesuai dengan kemampuan yang dimiliki tentang hal-hal yang mereka butuhkan dalam urusan dunia dan keagamaan", Menurut Syekh Ali bin Shalih al-Mursyidi dakwah adalah; "Syistem yang berfungsi menjelaskan kebenaran, kebajikan, dan petunjuk (agama); sekaligus menguak berbagai kebatilan beserta media dan metodenya melalui sejumlah teknik, metode dan merdia yang lain"8.

Menurut Syekh Adam Abdullah al-Aluri dakwah adalah: "Mengarahkan pandangan dan akal manusia kepada kepercayaan yang berguna dan kebaikan yang bermanfaat. Dakwah juga kegiatan mengajak (orang) untuk menyelamatkan manusia dari kesesatan yang hampir menjatuhkannya atau dari kemaksiatan yang selalu mengelilinginya. ${ }^{9}$

\section{B. Tinjauan Tentang Sumber dan Metode Dakwah}

Munzier dalam bukunya "Metode Dakwah" menulis 4 hal yang menjadi sumber metode dakwah yaitu, Al-Qur'an, Sunnah Rasul, Sejarah para sahabat dan fuqaha dan pengalaman ${ }^{10}$.Dakwah sebagai suatu usaha pengejawantahan misi suci Islam sebagai rahmatan

\footnotetext{
${ }^{2}$ Maulana Muhammad Zakariya al-Kandahlawi, Himpunan Fadhailul A'mal, terj. Abdurrahman Ahmad, Yogyakarta : As-Shaf, 2006.

${ }^{3}$ Syeikh Mulana Muhammad Yusuf al-kandahlawi yang disusun kembali oleh Maulana Muhammad Saad al-Kandahlawi, Muntakhab Ahadits : Dalil-dalil pilihan enam sifat utama, Yogyakarta : As-Shaf, 2006.

${ }^{4}$ Maulana Sayid Muhammad Syahid, Menjawab kritikan atas kitab Fadhailul A'mal, Bandung : Pustaka Dai, 2003.

${ }^{5}$ Maulana Wahiduddin Khan, Tabligh Movement, New Delhi : The Islamic Center, 1997

${ }^{6}$ Yunus, Mahmud dan Muhammad Qasim Bakry. 1930. Al-Qāmūs al-Zahabiy. Mesir: Al Mathba'ah Al-Rahmaniyah.h.112

${ }^{7}$ Muhammad Ali Aziz. 2009. Ilmu Dakwah. Jakarta: Kencana.h.11.

${ }^{8}$ Muhammad Ali Aziz. 2009. Ilmu Dakwah

${ }^{9}$ Ibid, h.12.

${ }^{10}$ Munzir Suparta dan Hajani Hefni, ed. 2006. Metode Dakwah. Jakarta: Kencana.h.20
} 
lil'alamin haruslah digali dari sumber utama ajaran Islam yaiu Al-Qur'an Sunnah Rasulullah saw, sebagaimana pesan terakhir Rasulullah dalan pidatanya pada Haji Wad' sebagai berikut: "Perhatikan kata-kataku ini, saudara-saudara. Aku sudah menyampaikan ini, ada masalah yang sudah jelas kutinggalkan di tangan kamu, yang jika kamu pegeng teguh, kamu takkan sesat selama-lamanya,-Kitabullah dan Sunnah Rasulullah"11. Berangkat dari khutbah Rasulullah pada Haji Wada' itu, Semua aktifitas umat Islam haruslah didasarkan kepada Al-Qur'an dan Sunnah Rasulullah, maka adalah merupakan suatu kepastian bahwa dakwah harus didasarkan kepada AlQur'an dan SunnaRasulullah (Q.S.Al-Anfal, 8: 20).

Selain Al-Qur;an dan Al-Sunnah, sejarah hidup para sahabat dan fuqaha juga dapat dijadikan sebagai sumber dakwah. Dalam sejarah kehidupan para sahabat dan para fuqaha banyak nilai-nilai yang patu dijadikan suri tauladan dal usaha dakwah. Karerna adalah orasng-orang yang ekpert dalam bidang agama. Mu'adz bin Jabal dan para sahabat lainnya merupakan figure yang patut dicontoh sebagai kerangka acuan dalam mengembangkan misi dakwah ${ }^{12}$. Pengalaman juru dakwah juga merupakan sumber metode dakwah yang signifikan dalam berdakwah.

\section{Tinjauan Pustaka tentang Pendekatan Dakwah}

Pendekatan dakwah sesungguhnya tidaklah berdiri sendiri tetapi saling bertautan dengan aspek-aspek lain yang terkait dengan dakwah. Menurut Muhammad Ali Aziz, ketika dia membahas metode dakwah ada beberapa istilah yang saling berkaitan, yaitu pendekatan (approach-nahiyah), strategi (strategy-manhaj), metode (method-ushlub) teknik (techniquethariqah), dan taktik (tactic-syakilah) ${ }^{13}$. Dalam penelitian ini tidak semuanya akan diteliti, tetapi hanya difokuskan kepada pendekatan dakwah.

Pendekatan dakwah berada di antara dua kutup, pada satu sisi adalah da'i, sebagai subjek yang mengajak dan pada sisi lain ada mad'u sebagai objek yang diajak. Agar antara da'i dengan mad'u tercipta keselarasan dan keharmonisan perlu adanya bentuk pendekatan yang akurat. Menurut Sjahudi Siradj sebagaimana dikutip oleh Muhammad Ali Aziz; ada tiga pendekatan dakwah ${ }^{14}$. Pendekatan budaya, Pendekatan pendidikan, danPendekatan psikologis.Ketiga pendekatan dakwah tersebut lebih banyak ditentukan oleh kondisi mad'u sebagai objek dakwah. Oleh karenanya komponen terkait, da'i, materi atau pesan dakwah, metode dakwah, dan media dakwah harus singkron dengan kondisi objek yang didakwahi. Sesuai dengan misi Islam rahmatan lilalamin, maka pendekatan dakwah haruslah dilakukan dan diseberluaskan dengan semangat kasih sayang, santun dan simpatik. ${ }^{15}$

Menurut Syekh Mustafa Mansur dalam buklunya 'Fiqhud Dakwah" sebagaiman di kutip oleh Munzir Suparta, ada dua hal yang menjadi dasar bahwa pendakatan dakwah Islam tidak harus menggunakan pendekatan kekerasan tetapi justru harus dilakukan dengan penuh kelembutan,santun dan kasih sayang. Pertama, Islam adalah agama yang benar dan ajaranajarannya sama sekali benar dan dapat diuji kebenarannya secara ilmiah. Dua, Masuknya iman ke dalam kalbu setiap manusia merupakan hidayah dari Allah tidak seorangpun yang berhak dan mempu memberikan hidayah ke dalam kalbu manusia kecuali hanya Allah SWT ${ }^{16}$

\section{Tinjauan tentang Sejarah Singkat Jamaah Tabligh}

Jama'ah Tabligh didirikan oleh Syaikh Maulana Ilyas bin Syaikh Muhammad Ismail AlKandahlawi Al-Hanafi di Negara India, tepatnya di kota Sahar Nufur. Beliau dilahirkan tahun 1303 H. di lingkungan keluarga yang mengikuti thariqat Al-Jitsytiyyah ash-Shufiyyah. Ia belajar pertama kali pada kakeknya sendiri, Syeikh Muhammad Yahya, seorang guru madrasah di kota kelahirannya. Kakenya ini adalah seorang penganut madzhab Hanafi dan teman dari sorang ulama

\footnotetext{
${ }^{11}$ Muammad Husain, Haekal. 1982. Sejarah Hidup Muhammad. Jakarta: Tintamas.h.609

${ }^{12}$ Munzir Suparta dan Hajani Hefni. Op.Cit, h.21

${ }^{13}$ Muhammad Ali Aziz. Op.Cit. h.345.

${ }^{14}$ Ibid, h.347.

${ }^{15}$ Ibid, h. 348

${ }^{16}$ Munzir Suparta dan Hajani Hefni, Op.Cit. h.64.
} 
dan penulis Islam terkenal, Syeikh Abu Al-Hasan Ali al-Hasani an-Nadawi, direktur Dar-Ulum di Lucknow, India. ${ }^{17}$ Beliau orang yang hafidz (hafal Qur'an) dan menimba ilmu di Madrasah Diyuband setelah diba'iat oleh guru besar Thariqat, Syaikh Rasyid Ahmad Al-Katskuhi. ${ }^{18}$

Maulana Ilyas pertama kali terdorong untuk mendirikan Jama'ah Tabligh setelah melihat adanya kerusakan mental umat Islam. Menurut penilaiannya, mental umat Islam sudah bobrok dan banyak masjid yang kosong, ibadah-ibadah wajib sudah banyak ditinggalkan oleh umat Islam. Banyak orang mengaku beriman Islam, tetapi sebenarnya mereka telah terjatuh ke lembah kemusyrikan. Maulana berpendapat, tidak ada jalan untuk memperbaikinya kecuali dengan kembali kepada ajaran Rasulullah SAW. Cara inilah yang dapat menyembuhkan "orang-orang sakit" itu.

Pusat perkembangan jama'ah tabligh ada di India, tepatnya perkampungan Nidzammudin, Delhi. Mereka memiliki masjid sebagai pusat tabligh yang dikeliliingi oleh 4 kuburan wali. Mereka terkesan sangat mengagungkan masjid tersebut dan menganggap suci masjid yang ada kuburannya tersebut. Da'wah jama'ah tabligh menyebar hingga ke Pakistan, Bangladesh dan negara-negara asia timur dan menyebar hingga ke seluruh dunia. Tujuan dakwah mereka adalah membina ummat islam dengan konsep khuruj/jaulah ${ }^{19}$ yang lebih menekankan kepada aspek pembinaan suluk/akhlak, ibadah-ibadah tertentu seperti dzikir, zuhud, dan sabar.

Di Indonesia Jamaah tabligh mulai masuk pada tahun 1952, tetapi baru berkembang pada tahun 1974 di Masjid Jami Kebon Jeruk, Jakarta Pusat. Pada awal tahun 1990-an, gerakan dakwah ini sudah tersebar di 27 propinsi di Indonesia. Dakwah dilakukan hingga kawasan transmigrasi dan ke penjara-penjara. Anggota Jamaah Tabligh di Indonesia sangat bervariasi, mulai dari artis seperti Gito Rollies sampai dengan tentara, kalangan profesional dll. Sasaran utama pengembangan Jamaah Tablig umumnya kalangan perkotaan terutama yang tidak menyukai aktivitas politik dan ada minat terhadap sufisme. ${ }^{20}$

\section{E. Aqidah dan Ajaran Jamaah Tabligh}

Gerakan Jama'ah Tabligh menetapkan enam pedoman dasar sebagai asas da'wah dari jamaah ini yang disebut dengan "Ushul Sittah", yang mana tersebut sebagai berikut:" (1) Al Kalimah Thoyyibah, yaitu dua kalimat syahadat, Kalimat syahadat dalam ajaran Jamaah Tabligh tidak hanya sebatas diucapkan saja. Akan tetapi, kalimat syahadat juga harus diterapkan dalam amaliyah sehari-hari, dan mereka mengartikan kalimat syahadat sebagai berikut: (a) Laa ilaaha ilallah, Maksudnya: Mengeluarkan keyakinan pada makhluk dari dalam hati dan memasukkan keyakinan hanya kepada Allah di dalam hati. Yaitu dengan cara sebagai berikut: Mendakwahkan pentingnya iman, latihan dengan membentuk halakah iman, berdoa kepada Allah agar diberi hakikat iman. (b) Muhammadar Rasulullah, Maksudnya: Mengakui bahwa satu-satunya jalan hidup untuk mendapatkan kejayaan dunia dan akhirat hanya dengan mengikuti cara hidup Rasulullah s.a.w. Yaitu dengan cara sebagai berikut: dakwahkan pentingnya sunnah Rasulullah, latihan dengan menghidupkan sunnah 1x24 jam setiap hari, berdoa kepada Allah agar dapat mengikuti sunnah Rasulullah.

(2) Melaksanakan sholat dengan khusyu', Para pengikut Jama'ah Tabligh sangat disarankan untuk mealakukan sholat dan melaksanakan amalan-amalan didalamnya baik yang wajib maupun yang sunnah. Artinya, shalat dengan konsentrasi batin dan rendah diri dengan mengikuti cara yang dicontohkan Rasulullah dan membawa sifat-sifat ketaatan kepada Allah dalam shalat kedalam kehidupan sehari-hari.

\footnotetext{
${ }^{17}$ Azra, Azyumardi [et.al.], Ensiklopedi Islam: Jilid 1, (Jakarta: ichtiar Baru Van Hoeve, 1996), h.266.

${ }^{18}$ Mani' bin Hammad al-Jahni, Al Mausuah al Muyassarah fil Adyan wal Madzahib wal Ahzab al Muashirah, (Riyadl: Darun Nadwah al Alamiyah, 1418H), h.321

${ }^{19}$ keluar wilayah untuk berdakwah dengan jumlah waktu yang telah ditentukan seperti 4 bulan, 40 hari, seminggu, dls.

${ }^{20}$ Azra, Azyumardi [et.al.], Op.Cit., h.268

${ }^{21} /$ Http:/Jamaahtabligh/MeandMyMind/JamaahTablighDanDakwah./html/ 15/03/2016
} 
(3) Al Ilm wa al Dzikr, Yang dimaksud dengan Al Ilm adalah bahwasanya semua petunjuk yang datang dari Allah telah diperlihatkan pada diri Rasulullah. Sedangkan Al Dzikr yaitu senantiasa mengingat kebesaran Allah.

(4) Ikramul Muslimin (Memuliakan sesama Muslim), Menunaikan kewajiban pada sesama muslim tanpa menuntut hak kita ditunaikannya. Yaitu dengan cara; Mendakwahkan pentingnya ikramul muslimin, Latihan dengan memberi salam kepada orang yang dikenal maupun yang tidak dikenal menghormati yang tua, menghargai yang sesama, menyayangi yang muda, Berdoa kepada Allah agar diberi hakikat ikrakul muslimin.

(5) Ikhlas, Membersihkan niat dalam beramal, semata-mata karena Allah. Yaitu dengan cara; Mendakwahkan pentingnya tashihun niyah, latihan dengan mengoreksi niat sebelum, saat dan setelah beramal, berdoa kepada Allah agar diberi hakikat tashihun niat.

(6) Dakwah dan tabligh khuruj fii sabiilillah, Dakwah dan tabligh adalah dengan memperbaiki diri, yaitu menggunakan diri, harta, dan waktu seperti yang diperintahkan Allah. Dan menghidupkan agama pada diri sendiri dan manusia di seluruh alam dengan menggunakan harta dan diri mereka. ${ }^{22}$

Gerakan Jamaah Tabligh mengajarkan bahwa taklid pada mazhab tertentu wajib hukumnya. Dengan demikian, gerakan ini berpendapat bahwa pintu ijtihad telah tertutup, karena sekarang ini tak ada ulama yang mampu melaksanakan ijtihad sehingga digelari mujtahid.

Jamaah ini banyak terpengaruh dengan tarikat-tarikat sufi yang ada di India. Oleh karena itu ada diantara ajaran-ajarannya yang bersumber dari ajaran tarikat sufi, diantaranya kewajibah Baiah kepada syeikh, mengagung-agungkan syeikh dan Rasulullah SAW, dan memperbanyak amalan-amalan tasawuf. ${ }^{23}$

\section{F. Prinsip dan Aktivitas Dakwah Jamaah Tabligh}

Markas internasional pusat tabligh adalah di Nizzamudin, India. Kemudian setiap negara juga mempunyai markas pusat nasional, dari markas pusat dibagi markas-markas regional/daerah yang dipimpin oleh seorang Shura. Kemudian dibagi lagi menjadi ratusan markas kecil yang disebut Halaqah. Kegiatan di Halaqah adalah musyawarah mingguan, dan sebulan sekali mereka khuruj selama tiga hari. Khuruj adalah meluangkan waktu untuk secara total berdakwah, yang biasanya dari masjid ke masjid dan dipimpin oleh seorang Amir. Orang yang khuruj tidak boleh meninggalkan masjid tanpa seizin Amir khuruj. Tapi para karyawan diperbolehkan tetap bekerja, dan langsung mengikuti kegiatan sepulang kerja. ${ }^{24}$

Berbeda dari pengertian umum yang memahami dakwah secara salah sebagai tugas para alim ulama semata, gerakan ini berpendapat bahwa amar makruf nahi munkar adalah kewajiban setiap muslim dan muslimah; dakwah bukan hanya kewajiban alim ulama melainkan juga kewajiban muslim awam. Oleh karena itu, gerakan ini kurang nyaman dengan kegiatan-kegiatan dakwah seperti tabligh akbar, apalagi hal itu disatukan dengan acara-acara kesenian tertentu.Setiap kali tiba di suatu daerah, mereka pertama-tama melakukan Jaulah Khususi, yaitu mengunjungi ulama setempat; baru kemudian mereka mengadakan Jaulah Umumi, yaitu mengunjungi rumah-rumah penduduk dan mengajak mereka ke masjid setempat. ${ }^{25}$ Kemudia kegiatan diisi dengan ta'lim (membaca hadits atau kisah sahabat, biasanya dari kitab Fadhail Amal karya Maulana Zakaria), bayan, mudzakarah (menghafal) 6 sifat sahabat, karkuzari (memberi laporan harian pada amir), dan musyawarah. Selama masa khuruj, mereka tidur di masjid. ${ }^{26}$

\footnotetext{
${ }^{22}$ http://id.wikipedia.org/wiki/Jamaah_Tabligh/15/03/2016

${ }^{23}$ Mani' bin Hammad al-Jahni, Op.Cit., h340

${ }^{24}$ http://www.asysyariah.com/print.php?id_online=153/15/03/2016

${ }^{25}$ Azra, Azyumardi [et.al.], Op.Cit., h. 267

${ }^{26}$ http://id.wikipedia.org, Op.Cit.
} 
Ada beberapa prinsip yang selalu harus diingat oleh anggota jamaah dalam menjalankan dakwah selama khuruj, diantaranya: ${ }^{27}$ (1) Dakwah harus dijalankan dengan Ikhlas dan hanya mengharap ridho Allah. (2) Anggota jamaah harus menghormati orang Islam yang lain, terutama para ulama. (3) Selama berdakwah, anggota jemaah diharuskan mempelajari ajaran gerakan dan selalu berusaha menjalankan ajaran itu. (3) Anggota harus menjahui perbuatan yang sia-sia dan sebaliknya memperbanyak ibadah seperti shalat sunnah. (4) Dalam member bayan, anggota diharapkan menggunakan kata-kata yang tepat, memberikan penjelasan yang menentramkan jiwa, dan dilarang bicara politik, menggunjing aib orang lain. (5) Penekanan bayan pada masalh kebesaran Allah, kepercayaan pada hari akhir, kewajiban shalat berjamaah dan kewajiban berdakwah. (6) Anggota harus bersabar bila mendapat sambutan yang tidak simpatik. (7) Kalau usaha dakwah gagal, kegagalan itu dianggap tidak terletak pada mereka melainkan pada pendengar yang masih enggan menerima kebenaran. (8) Anggota mengadakan evaluasi setiap selesai malakukan satu tindakan dakwah.

Aktivitas Markas Regional adalah sama, khuruj, namun biasanya hanya menangani khuruj dalam jangka waktu 40 hari atau 4 bulan saja. Selain itu mereka juga mengadakan malam Ijtima' (berkumpul), dimana dalam Ijtima' akan diisi dengan Bayan (ceramah agama) oleh para ulama atau tamu dari luar negeri yang sedang khuruj disana, dan juga ta'lim wa ta'alum.

Setahun sekali, digelar Ijtima' umum di markas nasional pusat, yang biasanya dihadiri oleh puluhan ribu umat muslim dari seluruh pelosok daerah. Bagi umat muslim yang mampu, mereka diharapkan untuk khuruj ke poros markas pusat (India-Pakistan-Bangladesh/IPB) untuk melihat suasana keagamaan yang kuat yang mempertebal iman mereka. ${ }^{28}$

\section{Metodologi Penelitian}

\section{A. Bentuk Penelitian}

Oleh karena kajian ini merupakan kajian etnografi, maka metodologi yang digunakan adalah kualitatif-deskriptif dengan analisa induktif.

\section{B. Tempat Penelitian}

Penelitian ini berlokasi di kota Mataram dengan pertimbangan bahwa markas (pusat) gerakan JT berada di kota Mataram iaitu di masjid at-Taqwa.

\section{Instrumen Penelitian}

Dalam penelitian ini yang menjadi instrumen utama adalah peneliti sendiri.

\section{Sampel Data}

Sumber data utama dalam penelitian ini ialah hasil wawancara dan fenomena. Adapun data sekunder ialah dokumen-dokumen yang terkait dengan subjek penelitian.

\section{E. Teknik Pengumpulan Data}

Teknik pengumpulan data dalam penelitian ini ialah wawancara, observasi dan dokumentasi. Teknik wawancara dan observasi dilakukan bagi memudahkan interaksi antara peneliti dengan kelompok yang menjadi objek penelitian. Adapun telaah dokumen diperlukan untuk melengkapi data yang diperlukan.

Dalam penelitian ini, teknik wawancara yang digunakan adalah wawancara mendalam dengan mengajukan beberapa pertanyaan terkait fokus permasalahan. Sedangkan pemilihan sampel dilakukan dengan cara purposive sampling sehingga memenuhi keperluan penelitian. Adapun jumlah responden yang akan diwawancara ialah minimal 21 orang. Adapun teknik observasi

\footnotetext{
${ }^{27}$ Azra, Azyumardi [et.al.], Op.Cit., h. 267

${ }^{28}$ Hakim, Abdul, Sudahkah Anda Mengenali Jama'ah Tabligh?, (Jakarta: Darul Qolam, 2003), h.24
} 
dalam penelitian ini dilakukan dengan cara mengamati secara langsung segala aktivitas yang dijalankan oleh gerakan JT di Majid at-Taqwa Mataram.

\section{F. Teknik Analisis Data}

Setelah semua data terkumpul maka langkah seterusnya adalah mengolah dan menganalisa data dengan cara menyusun data ke dalam kategori, melakukan sintesa, menyusun ke dalam pola lalu membuat kesimpulan sehingga mudah difahami.

\section{G. Tempo Penelitian}

Penelitian ini akan dijalankan selama enam (6) bulan mulai dari bulan Maret sampai bulan Agustus.

\section{Penyajian dan Analisis Data}

\section{A. Profil Jamaah Tabligh}

Jamaah Tabligh merupakan kelompok transnasional dakwah Islam yang didirikan pada tahun 1926M oleh Muhammad Ilyas di India. Kelompok ini melakukan gerakan dakwahnya dari kalangan bawah untuk merangkul seluruh kalangan masyarakat Muslim tanpa memandang status dan ekonomi. Selama dua dekade pasca dibentuk, gerakan ini telah berhasil menebarkan pengaruhnya di Asia Selatan sampai ke Asia Tenggara yang dipimpin oleh Maulana Yusuf putra Maulana Ilyas yang menjabat sebagai Amir.

Di setiap negara Jamaah Tabligh memiliki markas mulai dari tingkat pusat sampai ke daerahdaerah. Bahkan di daerah-daerah terdapat ratusan markas kecil yang biasanya dikenal dengan istilah halaqah dan halaqah ini terdiri dari sub halaqah kemudian mohalla (masjid-masjid atau mushalla-mushalla). Secara struktural markas dakwah Jamaah Tabligh terstruktur seperti berikut :

Markas dunia (Nizhamuddin) $>$ Markas negara $>$ Sub markas (daerah) $>$ Halaqah $>$ Sub halaqah > Mohalla (Masjid dan mushalla)

Halaqah merupakan ujung tombak aktivitas dakwah gerakan ini. Di sinilah program-program dakwah disusun baik program yang bersifat harian, mingguan maupun bulanan. Kegiatan harian antaranya musyawarah harian, taklim harian, zikir pagi dan petang dan amalan silaturrahmi. Adapun kegiatan mingguan berupa jaulah atau mengunjungi sesama Muslim dan berbincang tentang iman dan amal serta berusaha meningkatkan keimanan dan mempersiapkan diri untuk akhirat. Sedangkan kegiatan bulanan berupa khuruj (keluar) bersama-sama selama tiga hari ke masjid-masjid. Khuruj ini dimaksudkan untuk melakukan muhasabah diri dan mengajak orang lain agar berusaha meningkatkan iman. Selama khuruj biasanya ada empat aktivitas utama difokuskan. Pertama, dakwah kepada Allah (ad-da'wah ila Allah). Kedua, belajar dan mengajar (at-ta'lim wa at-ta'allum). Ketiga, zikir dan ibadah. Keempat, Khidmat (melayani sesama Muslim). Semua aktivitas yang dilakukan sepanjang khuruj ini akan dilaporkan setiap hari kepada Amir.

Aktivitas di markas regional tetap sama, hanya saja tempo khuruj lebih lama yaitu 40 hari sampai 4 bulan. Mereka juga mengadakan ijtima' yang diisi dengan bayān oleh para ulama atau para tamu dari luar negeri yang sedang khuruj di sana dan juga ta'lim wa ta'allum. Biasanya gerakan ini mengadakan ijtima' setahun sekali yang dihadiri oleh puluhan ribu umat Muslim di seluruh pelosok daerah. Adapun bagi Muslim yang mampu dianjurkan untuk khuruj ke markas pusat di India, Pakistan dan Bangladesh untuk melihat suasana keagamaan yang kuat untuk mempertebal iman.

\section{B. Landasan Utama Dakwah Jamaah Tabligh}

Ada enam asas atau landasan dakwah pergerakan Jamaah Tabligh yang dikenali dengan istilah enam sifat yaitu :

1. Kalimah Thayyibah yaitu La Ilaha Illa Allah. Muhammad Rasul Allah. Sifat pertama ini bertujuan untuk mengeluarkan keyakinan kepada makhluk dari dalam hati dan menghiasinya 
dengan keyakinan kepada Allah, supaya nanti ketika seseorang itu meninggal dunia dalam keadaan benar-benar beriman kepada Allah. Untuk mencapai sifat ini maka beberapa hal yang harus diamalkan yaitu berdakwah tentang pentingnya iman, latihan dengan cara membentuk majelis halaqah iman dan bersoa kepada Allah agar diberikan hakekat iman.

2. Shalat dengan khusyu dan khudhu' yaitu shalat yang diiringin dengan penuh konsentrasi bathin dan merendahkan diri di hadapan Allah s.w.t. serta dilakukan sesuai dengan tuntunan Nabi s.a.w. Sifat ini bertujuan membawa sifat-sifat ketaatan kepada Allah s.w.t. yang ada dalam shalat ke dalam kehidupan sehari-hari. Untuk mendapatkan sifat ini perlu melakukan dakwah mengenai pentingnya shalat dengan khusyu, melakukan latihan dengan cara memperbaiki tertib zahirnya shalat mulai dari istinja', wudhu, bacaan-bacaan dan gerakangerakan dalam shalat, seterusnya menghadirkan keagungan Allah s.w.t. dalam hati ketika shalat.

3. Ilmu dengan zikir yaitu mengamalkan segala perintah Allah s.w.t. di setiap waktu dan keadaan dengan menghadirkan keagungan Allah s.w.t. dalam hati serta dilakukan sesuai dengan tuntunan Nabi s.a.w. Ilmu menurut gerakan ini terbagi menjadi dua yaitu ilmu fadha'il (keutamaan amal) dan ilmu masa'il (hukum). Agar seseorang dapat memiliki ilmu fadha'il, maka hendaklah senantiasa berdakwah mengenai pentingnya ilmu fadha'il, melatih diri dengan memperbanyak halaqah ta' lim mengenai ilmu fadha'il, menghadirkan keutamaan amal dalam setiap amalan kemudian selalu berdoa kepada Allah. Adapun untuk memperoleh ilmu masa'il dilakukan dengan berdakwah akan pentingnya ilmu ini, latihan dengan cara sering duduk dalam halaqah ta'lim ilmu masa'il, bertanya kepada ulama tentang masalah dunia dan agama, berziarah kepada ulama dan senantiasa berdoa. Sedangkan untuk mebiasakan diri agar selalu zikir pada Allah maka perlu dilakukan dakwah tentang pentingnya zikir, latihan dengan cara konsisten membaca al-Qur'an setiap hari, zikir pagi dan petang, tasbih 100 kali sambil menghadirkan ke-Mahasuci-an Allah s.w.t. dalam hati, shalawat sebanyak 100 kali sambil menghadirkan perasaan betapa besar dan jasa Rasulullah s.a.w. kemudian istighfar sebanyak 100 kali sambil menghadirkan perasaan betapa banyak dosa-dosa kita dan betapa Allah Maha Pengampun, mengamalkan doa-doa masnunah dan adab-adabnya.

4. Memuliakan sesama Muslim (ikramul Muslimin) yaitu menunaikan hak-hak sesama saudara Muslim tanpa menuntut hak-hak kita dari mereka. Untuk mendapatkan sifat ini maka perlu dilakukan dakwah tentang pentingnya memuliakan sesama Muslim. Melakukan latihan dengan cara memuliakan ulama, menghormati orang yang lebih tua, menghargai yang seusia dan menyayangi yang lebih muda, memberi salam kepada orang yang dikenal maupun yang tak dikenal, bergaul dengan orang-orang yang berbeda watak serta berdoa.

5. Memperbaiki atau membetulkan niat (tashihun niyyah) yaitu membesihkan niat dalam setiap amal dari niat-niat lain kecuali hanya untuk mendapatkan ridha Allah s.w.t. Untuk memperoleh sifat ini harus dilakukan dakwah mengenai pentingnya ikhlas dan memperbaiki niat, melakukan latihan dengan melihat kembali niat kita sebelum beramal, ketika sedang beramal dan setelah beramal serta berdoa.

6. Dakwah dan Tabligh yang bertujuan memperbaiki diri yaitu dengan menggunakan harta dan diri sendiri sesuai dengan perintah Allah s.w.t., menghidupkan agama secara sempurna pada diri sendiri dan seluruh manusia dengan cara Rasulullah s.a.w. Untuk merealisasikan tujuan ini maka perlu dakwah mengenai pentingnya dakwah dan tabligh, melakukan latihan dengan keluar di jalan Allah s.w.t. minimal 4 bulan seumur hidup, 40 hari setiap tahun 3 hari setiap bulan dan 2.5 jam setiap hari kemudian berdoa.

Enam sifat inilah yang kemudian dikembangkan oleh Jamaah Tabligh ke dalam pola dakwah dengan karakteristik yang berbeda dengan gerakan-gerakan atau kelompok-kelompok mainstream lain dalam Islam. Jamaah Tabligh lebih banyak memfokuskan dakwah mengenai keutamaan ibadah (iman dan amal). Kelompok ini juga cenderung menghindari diskusi fiqih dan akidah untuk mengelakkan perpecahan umat.

Ketika mengadakan $t a '$ 'lim kelompok ini berusaha sebisa mungkin duduk merapat kepada nara sumber serta duduk berdempet-dempetan dengan pendengar lain sambil menunduk. Kegiatan 
ta'lim biasanya dilakukan setiap selesai shalat fardhu di mana mereka secara bergantian akan membaca kitab-kitab khusus yang menjadi pegangan mereka. Jika mereka bermalam di suatu masjid, mereka akan memberikan ta'lim kepada Jamaah shalat dengan menyampaikan hadits atau ayat al-Qur'ân. Saat makan mereka berkumpul membentuk lingkaran mengelilingi talam dan mereka menggunakan tiga jari untuk menyuap nasi. Adab duduk tatakala makan adalah menduduki kaki kiri dan kaki kanan dalam posisi seperti jongkok. Mereka tidak pernah menyisakan apapun dalam piring mereka, meskipun itu sebutir nasi. Sebagian mereka hanya mempraktekkan cara makan ini tatkala di luar rumah, namun bila mereka berada di rumah mereka makan seperti umumnya orang lain makan, dengan lima jari atau menggunakan alat bantu makan, dan duduk bersila atau di atas kursi.

Dalam perilaku sehari-hari membudayakan salam merupakan aktifitas yang selalu diutamakan oleh Jamaah Tabligh bukan saja terhadap sesama anggota tetapi juga terhadap sesama Muslim. Dalam berkomunikasi, Jamaah Tabligh selalu menghiasi tutur kata dengan kalimat-kalimat yang baik seperti Ma sya Allah, In sya Allah, subhanallah, Allahu Akbar, al-hamdu lillah. Mereka juga senantiasa bersikap tawadhu', sopan dan menghargai pendapat orang lain.

Dari segi penampilan, pengikut gerakan Jamaah Tabligh memiliki ciri khas yang mudah dikenali. Mereka biasanya memakai baju separas lutut yang sebenarnya merupakan pakaian khas masyarakat India yang dikenali dengan istilah Afghan cloths, bersorban, memakai celana di atas mata kaki. Mereka juga kerap menggunakan celak dan parfum bebas alkohol. Bagi para wanita pula mereka menutup seluruh anggota badan kecuali wajah dan telapak tangan dalam setiap aktivitas. Mereka senantiasa memakai sugi/siwak Ketika berjalan, golongan ini cenderung menundukkan kepala bagi menghindarkan pandangan mata yang membangkitkan syahwat.

Karakteristik dakwah yang dimiliki oleh Jamaah Tabligh ini ternyata mampu menarik banyak orang untuk menyertai gerakan ini. Walaupun secara statistik sukar untuk memastikan jumlah anggota Jamaah Tabligh di Lombok, namun dapat dipastikan jumlah anggota gerakan ini senantiasa bertambah setiap tahun. Menurut salah satu responden, setiap malam Jumaat terdapat lebih dari 3.000 orang yang ikut melakukan ijtima' di masjid raya at-Taqwa Mataram. Jumlah ini cukup untuk menggambarkan betapa gerakan ini memiliki pengaruh yang cukup luas di kalangan masyarakat Muslim pulau Lombok.

Secara umum metode dakwah yang diterapkan oleh Jamaah Tabligh dapat disimpulkan sebagai berikut : (1) Metode tabsyīr yaitu menyampaikan kabar gembira dalam bentuk keutamaan-keutamaan amal kebaikan. Dalam hal ini Jamaah Tabligh cenderung mengutip hadishadis yang membicarakan ganjaran pahala kebaikan dan surga. (2) Metode uswah/teladan yaitu dengan memberi contoh perilaku dan amalan Nabi s.a.w. baik dalam tutur kata, sikap dan perbuatan keseharian. (3) Metode Tasykīl yaitu Usaha untuk mengajak orang lain dengan memberikan pencerahan agar dapat meluangakan waktu di jalan Allah s.w.t. (4) Metode Jaulah door to door yaitu berkeliling menemui orang banyak dari rumah ke rumah agar taat kepada Allah. (5) Metode Ta'līm dan bayān yaitu majelis pencerahan untuk menjelaskan kelebihankelebihan amal dan tujuan menjalankan tabligh.

\section{Dampak Dakwah Jamaah Tabligh terhadap Pembangunan Masyakarat Muslim}

Melihat karakteristik dan metode dakwah yang dijalankan oleh Jamaah Tabligh, sukar untuk membayangkan kelompok dapat memainkan peranan yang lebih aktif dalam membangun masyarakat Muslim terutama dalam bidang politik, ekonomi dan sosial. Hal ini karena :

1. Dasar pemikiran kelompok ini cenderung tertutup dan bersifat "tasauf amali" yang hanya tertumpu kepada iman dan fadhailul amal, sedangkan masyarakat Muslim Lombok belakangan ini cenderung bersifat terbuka terutama kaitannya dengan pemikiran-pemikiran keagamaaan.

2. Dari aspek politik, gerakan Jamaah Tabligh nampaknya juga sukar untuk memainkan peranan lebih jauh dalam membangun masyarakat Muslim karena gerakan ini sama sekali tidak memiliki ghirah politik bahkan cenderung menjaga jarak dengan dunia politik apalagi bicara tentang khilafah Islam. Sikap gerakan ini jauh berbeda dengan situasi perkembangan 
politik di daerah-daerah termasuk pulau Lombok terutama setelah pemberlakuan otonomi daerah.

3. Begitu juga dari aspek ekonomi, doktrin-doktrin mengenai nilai-nilai ekonomi Islam di tengah-tengah serangan badai hedonisme, kapitalisme dan sosialisme tidak nampak sedikitpun dalam visi dakwah Jamaah Tabligh. Sementara pemerintah daerah pada hari ini sedang berupaya melakukan "Islamisasi" terhadap beberapa komponen ekonomi seperti keuangan dan pariwisata.

4. Dari aspek pelestarian adat pula, gerakan Jamaah Tabligh seakan-akan bersikap acuh tak acuh dengan adat budaya serta kearifan lokal yang ada pada masyarakat setempat. Misalnya dari segi berpakaian, kelompok ini lebih mengutamakan pakaian ala "Afghan clothes" di banding memakai batik apalagi pakaian adat. Sementara masyarakat Lombok adalah masyarakat "taat adat" yang senantiasa menjaga menjaga dan melindungi kelestarian adat.

Namun demikian tidak bermakna bahwa gerakan ini tidak menancapkan pengaruh dalam kehidupan sosial masyarakat. Justru dalam konteks masyarakat Lombok gerakan ini memiliki pengaruh yang cukup besar terhadap pembangunan spiritual tidak hanya di kalangan masyarakat kelas bawah tapi juga kelas menengah dan atas. Bahkan di kalangan elit masyarakat terutama pejabat tidak sedikit yang kebijakan-kebijakannya dipengaruhi oleh doktrin Jamaah Tabligh. Sebagai contoh H. L. Bakri seorang birokrat dan politisi yang pernah menjabat sebagai Plt. Bupati Kabupaten Lombok Utara pernah membuat suatu kebijakan khusus yang dinamakan Out Bond Spiritual (OBS) dengan mewajibkan para pejabat di lingkungan pemerintah daerah Kabubaten Lombok Utara untuk khuruj selama tiga hari ke masjid-masjid. Walaupun Jamaah Tabligh bersikap "anti" terhadap dunia politik namun gerakan ini telah mampu menanamkan doktrinnya kepada tokoh agama, pejabat dan politisi.

Di samping itu, dari aspek ekonomi dan gaya hidup Jamaah Tabligh telah mampu merubah pola hidup yang hedonis menjadi religius. Dari beberapa pernyataan responden yang penulis temui mengakui bahwa setelah bergabung dengan Jamaah Tabligh mereka merasakan perubahan yang amat besar dalam kehidupan sehari-hari padahal hanya beberapa bulan mereka bergabung dalam jamaah ini namun mereka merasa memiliki kehidupan yang lebih baik dari sebelumnya. Adapun dalam upaya melakukan Islamisasi terhadap sistem perekonomian nampaknya Jamaah Tabligh tidak memiliki upaya secara langsung ke arah itu. Berdasarkan analisa penulis, ada beberapa faktor mengapa dakwah ke arah Islamisasi ekonomi tidak dilakukan. Pertama, karena doktrin-doktrin yang menjadi landasan dakwah tidak sedikit pun menyentuh persoalan tersebut. Kedua, SDM di kalangan Jamaah Tabligh yang mengusai bidang ini sangat minim, karena berdasarkan strata pendidikan mayoritas masyarakat yang bergabung dengan gerakan ini berpendidikan SLTA ke bawah.

Tetapi yang menarik adalah walaupun kelompok ini tidak mampu untuk memberi pengaruh terhadap Islamisasi ekonomi, ternyata mereka memilki ghirah yang kuat untuk mengetahui praktik-praktik ekonomi Islam serta berupaya untuk melepaskan diri dari praktik-praktik ekonomi yang bertentangan dengan Islam.

Dari aspek sosial juga kehadiran Jamaah Tabligh setidaknya telah dapat mengurangi kejahatan di tengah-tengah masyarakat Lombok. Dari beberapa responden yang penulis temui terdapat beberapa di antaranya mengakui bahwa sebelum bergabung dengan Jamaah Tabligh mereka memiliki latar belakang kehidupan yang "gelap" ada di antara mereka yang pernah menjadi pencuri, perampok dan pecandu narkoba. Namun setelah bergabung dengan Jamaah Tabligh mereka merasakan perubahan yang amat besar dalam kehidupan mereka yang kini tidak lagi akrab dengan dunia gelap tapi justru menjadi pecinta ibadah. Di samping itu, gerakan Jamaah Tabligh juga telah mampu menghidupkan kembali suasana ibadah khususnya shalat berjamaah di beberapa masjid. Pengaruh ini sangat penting bagi masyarakat di pulau Lombok mengingat Lombok dikenal sebagai pulau seribu masjid. Berdasarkan pengamatan penulis, terdapat beberapa masjid di pulau Lombok yang sebelumnya "tidak hidup" dengan aktivitas ibadah kini menjadi "hidup" setelah dipengaruhi oleh Jamaah Tabligh seperti, Masjid di dusun Gelogor, desa Lendang 
Nangka, Lombok Timur, Perampuan Lombok Barat, Sekotong, Genggelang Lombok Utara, dusun Lekok Lombok Utara dan lain-lain.

Secara umum, terdapat beberapa pencapaian yang telah dihasilkan oleh gerakan Jamaah Tabligh dalam membangun masyarakat Muslim di Lombok antaranya : (1) Keberhasilan Jamaah Tabligh mempengaruhi golongan elit terutama di kalangan pejabat memberi dampak yang cukup besar terhadap upaya membangun sistem pemerintahan yang "Islami" seperti yang terjadi di Kabupaten Lombok Utara. (2) Hedonisme yang menjadi gaya hidup masyarakat perkotaan terutama golongan kelas menengah Masyarakat semakin berkurang. (3) Masyarakat semakin gemar melakukan amal ibadah terutama dalam melaksanakan Shalat berjamaah. (4) Peningkatan jumlah Jamaah mesjid sehingga semakin hari masjid semakin hidup makmur yang dengan sendirinya berdampak pada peningkatan ukhuwah islamiyah dan silaturahmi. (5) Suasana keislaman di masyarakat mulai hidup di mana tingkat kenakalan remaja semakin berkurang. (6) Semangat menggali pengetahuan keislaman semakin tinggi

Penulis juga menemukan beberapa kesan negatif dari pergerakan tabligh antaranya ialah :

1. Doktrin gerakan ini terlalu fokus kepada ibadah individual dan tidak begitu peduli dengan ibadah-ibadah sosial.

2. Menurut gerakan ini Islam dimaknai terlalu sederhana seolah-olah Islam tidak bicara tentang ekonomi, politik dan kekuasaan.

3. Pengabaian terhadap kehidupan keluarga terutama isteri dan anak-anak yang ditinggalkan dakwah. Penulis telah menemukan beberapa kasus terkait pengabaian terhadap keluarga dengan menemui salah seorang isteri seorang anggota Jamaah Tabligh di Rembiga, Mataram yang menyampaikan keluh kesahnya karena dia dan anak-anaknya ditinggal oleh suami berdakwah tanpa memberikan nafkah selama berbulan-bulan. Bahkan si isteri tersebut mengancam untuk menggugat cerai suaminya.

4. Penulis menilai bahwa kasus seperti ini tidak terjadi secara kebetulan dan bukan kasus pengecualian yang harus diabaikan. Kasus meninggalkan anak isteri di rumah tanpa memberi nafkah memiliki justifikasi yang kuat bagi kalangan Jamaah Tabligh antaranya : (a) Nabi Ibrahim meninggalkan istrinya dan anaknya Nabi Ismail di tengah gurun dimana Allah-lah yang mencukupi rizkinya, (b) Isteri yang ditinggal dirumah oleh suami yang sedang berdakwah tidak seberapa penderitaannya dibanding ketika berada di alam kubur sendiri. (c) Kepergian suami berdakwah di jalan Allah jauh lebih besar manfaatnya daripada pergi meninggalkan rumah untuk melakukan maksiat. Justifikasi seperti inilah yang kadang membuat isteri harus rela ditinggal suaminya berbulan-bulan untuk berdakwah walaupun menjalani hidup tanpa nafkah.

\section{Respon Masyarakat}

Kehadiran Jamaah Tabligh yang mengembangkan doktrin berbeda dengan kelompokkelompok mainstream di pulau Lombok tentu menimbulkan respon dan tanggapan yang beragam dari masyarakat. Secara umum penulis dapat membagi respon tersebut ke dalam tiga kategori :

1. Menolak : Kelompok yang menolak gerakan Jamaah Tabligh ini menilai bahwa Jamaah Tabligh meruakan pelaku bidaah karena menggunakan hadis-hadis dhaif dalam beramal. Bahkan gerakan ini juga dianggap sesat dan tidak sesuai dengan ajaran Islam. Selain karena alasan di atas, Jamaah Tabligh juga di anggap sebagai kelompok yang sering menelantarkan keluarga terutama istri dan anak-anak di rumah.

2. Menerima dan bergabung. Kelompok yang tertarik dengan dakwah Jamaah Tabligh bahkan terlibat secara langsung dengan program-program yang diadakan oleh kelompok ini serta ikut serta dalam kegiatan dakwah. Mereka yang menerima aktif ini dapat dikategorikan dalam tiga latar belakang : (a) Golongan yang memang sudah menjalankan ibadah Islam dengan baik namun kemudian merasakan kelezatan iman yang lebih tinggi saat mengikuti kegiatan dakwah Jamaah Tabligh. (b) Golongan yang masih labil pelaksanaan ajaran Islam yang kemudian termotivasi karena selama pergaulannya dengan anggota Jamaah Tabligh mengalami peningkatan keislaman dan keimanan. (c) Golongan yang sama sekali tidak 
mengamalkan ibadah atau ajaran Islam dan bahkan melakukan perbuatan yang bertentangan dengan ajaran Islam yang kemudian selama pergaulan dengan anggota Jamaah Tabligh mengalami pencerahan spiritual.

3. Menerima tapi tidak mau bergabung. Kelompok masyarakat yang merasa nyaman dengan kehadiran Jamaah Tabligh bahkan selalu hadir dalam setiap kegiatan yang diadakan namun tidak ikut serta dalam berdakwah.

4. Acuh tak acuh. Ini adalah golongan yang baginya ada atau tidak Jamaah Tabligh di daerahnya dia tidak ambil pusing, tidak menolak dan tidak menerima, dan tidak memberikan komentar dan respon apapun.

\section{Kesimpulan}

Demikianlah gambaran ringkas mengenai profil, doktrin dan pengaruh Jamaah Tabligh terhadap pembangunan masyakat Muslim di pulau Lombok. Menurut pandangan penulis, Jamaah Tabligh merupakan gerakan yang sejalan dengan doktrin ahlus Sunnah Wal-Jamaah hanya saja ajarannya tidak menyeluruh dan tidak komperhensip. Ini karena gerakan ini tidak memberi penekenan terhadap persoalan politik, ekonomi dan sosial. Bahkan ketika persoalan ini ditanyakan kepada responden mereka menjawab dengan jawaban yang hampir sama yaitu Rasulullah s. $a$. w. tidak pernah berpolitik dan tidak terlibat dengan pemilu atau pilkada. Begitu tentang persoalan mengenai sistem ekonomi, perundang-undangan dan tata negara mereka menjawab bahwa ketika seseorang sudah memiliki iman dan amal yang kuat maka dengan sendirinya segala bentuk perintah dan larangan Allah akan ditaati oleh mereka yang benar-benar yakin dengan Allah dan hari Kiamat.

Namun demikian, dari aspek amalan dan akhlak, Jamaah Tabligh memiliki militansi yang amat tinggi terutama dalam menjalankan ibadah shalat berjamaah. Demikian pula dengan akhlak ketika berdakwah, mereka tidak mengenal kata bosan, bahkan mereka sanggup membalas cacian dari orang-orang yang tidak suka dengan kehadiran mereka dengan senyuman dan penuh kerelaan. Inilah yang menjadi daya pemikat kelompok ini sehingga tidak sedikit dari masyarakat berbagai kalangan yang ikut bergabung.

Pengaruh yang ditanamkan oleh gerakan ini terhadap masyarakat Muslim di pulau Lombok tidak lah kecil terutama dalam membangun moral dan spiritual. Beberapa masjid yang pada awalnya sunyi kini menjadi hidup, individu yang pada awalnya hidup dalam dunia gelap kini telah kembali menemukan jati dirinya. Inilah contoh-contoh pencapaian yang dihasilkan oleh gerakan Jamaah Tabligh dalam membangun moral dan spritual masyarakat.

Tetapi walaupun usaha ke arah pemantapan iman dan amal yang dilakukan oleh kelompok ini memiliki kekuatan tersendiri untuk mendorong kekuatan akidah. Namun, dalam konteks hari ini penulis menganggap kelompok ini perlu menganalisa kembali doktrin-doktrin yang dianut agar dapat memberikan kontribusi yang lebih luas lagi dalam skop dan perspektif masa kini. Oleh karena itu penulis menyarankan agar Jamaah Tabligh sebaiknya tidak hanya fokus kepada kajiankajian hadis dan al-Qur'an secara literal saja, tapi hendaklah diperluas lagi skop dan cakupannya dengan mengkaji sumber-sumber sekunder lainnya yang dihasilkan oleh para ulama yang memahami tentang kandungan al-Qur'an dan Sunnah. Misalnya kitab-kitab tafsir, kitab-kitab hadis, atau kitab-kitab yang mengusung tema-tema kontemporer yang sejalan dengan pemikiran Islam. Sumber-sumber seperti ini harus lah disebar di tengah masyarakat dengan mengusung tema-tema yang dapat memberi kontribusi ke arah pemantapan akidah dalam segala aspek. 


\section{DAFTAR PUSTAKA}

Al- Qur'an dan Terjemah.

Abu Syadi. Syeikh Ayman. (t.th.) Nadzarah 'ilmiyyah di ahlit tabligh wad da'wah, Maktabah al-Majallat al-Arabiy : Cairo.

Aziz, Muhammad Ali. 2009. Ilmu Dakwah. Jakarta:Kencana.

Azra, Azyumardi [et.al.], Ensiklopedi Islam: Jilid 1, Jakarta: ichtiar Baru Van Hoeve, 1996.

Anshari, Furqan Ahmad. 2000. Pedoman Bertabligh Bagi Ummat Islam. Yogyakarta: AshShaff.

Benda harry J. et al (Penyt.). 1974. Islam di Indonesia: Sepintas Lalu Tentang Beberapa Segi. Jakarta: Tintamas Indonesia.

Darussalam dkk. 2011. Dakwah Jemaah Tabligh, Salatiga, STAIN Salatiga, 2011.

Esposito John L. Islam dan Pembangunan (terj. Sahat Simamora). 1992. Cetakan ke-2. Jakarta : PT. Rineka Cipta.

Haekal, Muammad Husain. 1982. Sejarah Hidup Muhammad. Jakarta: Tintamas.

Hakim, Abdul, 2003. Sudahkah Anda Mengenali Jama'ah Tabligh?, Jakarta: Darul Qolam.

Jurjis. 2001. Perilaku Berdakwah Jamaah Tabligh. Proposal. Makassar: Pascasarjana Universitas Negeri Makassar.

Krishnamurthi, Y. Bayu. 1994. Metode Penulisan Sosial Ekonomi. Jakarta: Dirgutiswa Dirjen Pendidikan Tinggi.

Leeman. Albert. 1989. Internal and external factor of socio-cultural and socio-economic dynamic in Lombok, Zurich: Universitat Zurich.

Manshur, Maulana Muhammad. 2000. Masturah (Usaha Dakwah di Kalangan Wanita). Bandung: Pustaka Ramadhan.

Mahbub ul Haq .1995. Reflection of Human developement. New York. Oxford of University Press.

Maulana Muhammad Zakariya al-Kandahlawi. 2006. Himpunan Fadhailul A'mal, terj. Abdurrahman Ahmad, Yogyakarta : As-Shaf.

Maulana Sayid Muhammad Syahid, 2003, Menjawab kritikan atas kitab Fadhailul A'mal, Bandung : Pustaka Dai.

Maulana Wahiduddin Khan, Tabligh Movement, New Delhi : The Islamic Center, 1997

Moleong, Lexy J. 2012, Metodologi Penelitian Kualitatif, Bandung: PT Remaja Rosdakarya.

Mulkhan, Abdul Munir. 2000. Neosufisme dan Pudarnya Fundamentalisme di Pedesaan. Yogyakarta: UII Press.

Mani' bin Hammad al-Jahni, Al Mausuah al Muyassarah fil Adyan wal Madzahib wal Ahzab al Muashirah, Riyadl: Darun Nadwah al Alamiyah, $1418 \mathrm{H}$

Rusdi Muhtar. Teknik Penulisan Ilmiah (Bidang IPS): Modul Diklat Fungsional Penulis Tingkat Pertama. (Cibinong: Pusat Pembinaan Pendidikan dan Pelatihan Penulis Lembaga Ilmu Pengetahuan Indonesia (LIPI). 2007

Syeikh Mulana Muhammad Yusuf al-kandahlawi yang disusun kembali oleh Maulana Muhammad Saad al-Kandahlawi, 2006. Muntakhab Ahadits : Dalil-dalil pilihan enam sifat utama, Yogyakarta : As-Shaf. 
Sayyid Abul Hasan Ali Nadwi, Riwayat Hidup dan Usaha Dakwah Maulana Muhammad Ilyas Rah.a.(Yogyakarta: Asshaf, 1999),

Suprayitno, Aktivitas Jamaah Tablgih Di Medan Dalam Transformasi Nilai-Nilai Agama Islam (Pusat Penulisan IAIN Sumatera Utara Medan: www.litagama.org). 25 Juni 2007.

Suparta, Munzir, dan Hajani Hefni, ed. Metode Dakwah. Jakarta: Kencana 2006.

Yunus, Mahmud dan Muhammad Qasim Bakry. 1930. Al-Qāmūs al-Zahabiy. Mesir: Al Mathba'ah Al-Rahmaniyah. 